\title{
Multiple Roles of Endophytes in Modern Agriculture
}

\author{
S. Maiyappan ${ }^{1 *}$, Devendra Kumar ${ }^{2}$ and T.G. Prasad ${ }^{3}$ \\ ${ }^{1}$ Department of Microbiology, ${ }^{2}$ Department of Chemistry, ${ }^{3}$ Department of Crop Physiology, \\ P J Margo Pvr Ltd., R\&D Research Centre, Bangalore, Karnataka, India \\ *Corresponding author
}

\section{A B S T R A C T}

\section{Keywords}

Endophyte, Biodiversity, Plant growth promotion, Phytohormones, Secondary metabolites

\section{Article Info}

Accepted:

20 July 2020

Available Online:

10 August 2020
Endophyte biology is an emerging field for practical use of beneficial microorganisms to control plant diseases and to sustain and assist crop production under non stress and stress conditions. Endophytes are microorganisms (fungi and bacteria) that colonize inside the plant tissues. The exact biological and biochemical roles of endophytes and their interactions with host plants in improving plant health and crop productivity is under investigation in many laboratories around the world. However, this has not stopped investigators in exploring the direct utility of endophytes in boosting crop production. Endophytes produce a myriad of biologically active compounds which includes plant growth promoting agents, antimicrobial agents, phytohormones, antibiotics, antioxidants, anticancer agents, immunosuppressive compounds and compounds with insecticide properties. This review is intended to provide background information on aspects of developments in endophyte biology and more importantly the roles of endophytes in modern agriculture.

\section{Introduction}

The existence of endophytes has been known for over one hundred years. They live as imperfect fungi most of the time and have been described as benign parasites or true symbionts. They can influence the distribution, ecology, physiology and biochemistry of the host plants (Sridhar and Raviraja, 1995). Endophytes were intensively studied during the past decades for the great potential of novel valuable metabolites which have medicinal, agricultural and industrial applications (Owen and Hundley, 2004). Endophytes are bacterial or fungal microorganisms that colonize healthy plant tissue intercellularly (apoplasts) and/or intracellularly (symplast) without causing any apparent symptoms of disease (Wilson, 1995).All plant species that exist on the earth, is host to one or more endophytes (Strobel et al., 2004). Only a few of these plants have been completely studied relative to their endophytic biology, endophytes are ubiquitous, colonize in all plants and have been isolated from almost all plants. Endophytic fungi represent an important and quantifiable component of fungal biodiversity and are known to affect plant community diversity and structure (Krings et al., 2007). 
Many endophytes are members of common soil bacterial genera, such as Pseudomonas, Burkholderia and Bacillus (Lodewyckx et al., 2002). These genera are well known for producing diverse range of secondary metabolic products including antibiotics, anticancer compounds, volatile organic compounds, antifungal, antiviral, insecticidal and immunosuppressant agents. Endophytes can be beneficial to their host by producing a range of natural products that could be harnessed for potential use in medicine and agriculture industry. It has been shown that they have the potential to remove soil contaminants by enhancing phytoremediation and may play a role in soil fertility through phosphate solubilization and nitrogen fixation. Plants strictly limit the growth of endophytes and these endophytes use many mechanisms to gradually adapt to their living environments (Dudeja et al., 2012). Endophytic population varies from plants to plants and from species to species. There is increasing evidence showing the presence of ubiquitous endophyte species in tropical and temperate forests. Different endophytes have been identified from different plant tissues. The biodiversity of endophytes can be judged by the potential of microbes to colonize the tissues and persist in the plant (Rosenblueth and Martinez-Romero, 2006).

They can infect plants from the soil and are competent root colonizers. The variation in the endophytic communities can be attributed to bacterial species, plant genotype, plant developmental stage, colonizing tissue type, soil type and environmental conditions (Kobayashi and Palumbo, 2000). Endophytic bacteria have been isolated from both monocotyledonous and dicotyledonous plants, ranging from woody tree species, such as oak and pear, to herbaceous crop plants such as sugar beet and maize. These organisms generally colonize the intercellular spaces, and they have been isolated from all plant compartments including seeds (Posada and Vega, 2005). Investigation of the biodiversity of endophytic strains for novel metabolites may identity new drugs for effective treatment of diseases in humans, plants and animals (Strobel et al., 2004).Dual culture has been successfully used in studying the physiological and morphological interactions between fungal endophytes and plant cells (Huang et al., 2017). Banana trees have more endophytes in the roots $(67 \%)$ than in the cortex $(23 \%)$ or central cylinder $(10 \%)$ (Pocasangre et al., 2000).

To date, few endophytic bacterial genome sequences have been published; however, genome sequencing of a number of endophytes including Enterobacter sp.638, Stenotrophomonas maltophilia R551-3, Pseudomonas putida W619, Serratia proteamaculans 568 and Methylobacterium populi BJ001 is underway at the United States Department of Energy Joint Genome Institute (www.jgi.doe.gov).Improvement of endophyte resources could bring us a variety of benefits, such as novel and effective bioactive compounds that cannot be synthesized by chemical reactions. The metabolic impacts of endophytes on host plant may employ pathways of i) endophytes self-metabolizing ii) endophytes and host cometabolizing and iii) Signalling (LudwigMuÈ 1ler, 2015).

\section{Endophytes - Role in nutrient acquisition by plants}

Endophytes may produce overabundance of substances of potential use to agriculture, industry and modern medicine such as novel antibiotics, antimycotics, immunosuppressant and anticancer compounds (Mitchell et al., 2008). Endophytic bacteria show more plant growth promoting effects than bacteria found in the rhizosphere (Dawwam et al., 2013). Endophytes are well known for their potential 
to improve plant growth by direct and indirect mechanisms. Direct mechanisms involve the microbial synthesis of phytohormones for example, production of Indole-3-acetic acid (IAA), ethylene like, Cytokinin like and gibberellins like substances. In addition, these endophytic bacteria also have the ability of nitrogen fixation (Latif et al., 2013). Indirect mechanisms include assisting plants in acquiring nutrients via phosphate solubilisation, nitrogen fixation and siderophores production. Besides these mechanisms, plant-associated microorganisms improve nutrient acquisition by supplying minerals and other micro/macro nutrients from the soil (Barrow, 2003).

Endophytes promote plant growth, by adopting various mechanisms which includes phosphate solubilisation activity (Wakelin et al., 2004). Abid Ullah et al., 2018 reported that, endophytic Enterobacter sp solubilize phosphate on a large scale. Ahemad and Khan, 2010; Lopez et al., 2011 have reported that E. asburiae a potential plant growth promoting bacteria has ability to solubilize large amount of phosphates. It is reported that endophytes solubilize the inorganic phosphorus by reducing the $\mathrm{pH}$ through the excretion of organic acid, while organic phosphorous is solubilized by production of various phosphatases, which results in a better plant development and improved yield (Rodriguez and Fraga, 1999).

Nutrient acquisition for plants via nitrogen fixation is another mechanism behind plant growth promotion. Many species of endophytic nitrogen fixing bacteria have been isolated from sugarcane (Loiret et al., 2004) and other plants, e.g., rice, kallar grass and maize, and these bacteria supply fixed nitrogen $(\mathrm{N})$ to their hosts (Baldani et al., 2002). Symbiotic associations between sugarcane and its endophytic nitrogen fixing bacteria provide mutual benefits such as a combined $\mathrm{N}\left(\mathrm{NH}_{3}\right)$ supply to the plant and photosynthates to the bacteria. Many genera of endophytic nitrogen fixing bacteria were generally Gram-negative (Loiret et al., 2004).

\section{Endophyte - Role in Phytohormone production}

Phytohormone production by endophytes is probably the best-studied mechanism of plant growth promotion, leading to morphological and architectural changes in plant hosts. Endophytic bacteria produce a wide range of phytohormones, such as auxins, Cytokinins, and gibberellic acids. Burkholderia vietnamiensis, a diazotrophic endophytic bacterium isolated from wild cottonwood (Populus trichocarpa), produced indole acetic acid (IAA), which promotes the growth of the plants (Xin et al., 2009). A new strain of fungus Cladosporium sphaerospermum isolated from the roots of Glycine $\max (\mathrm{L})$ Merr. showed the presence of higher amounts of bioactive GA3, GA4, and GA7, which induced maximum plant growth in both rice and soybean varieties (Hamayum et al., 2009). The beneficial effects of bacterial endophytes on their host plant appear to occur through similar mechanisms as of rhizosphere-associated bacteria. These mechanisms have been reviewed in great detail by Kloepper et al., (1999) or, more recently, by Compant et al., (2005).

A different mechanism for plant growth promotion by endophytes exists in addition to production of plant growth hormones. Adenine and adenine ribosides have been identified as growth-promoting compounds in endophytes of Scots pine (Pirttilä 2004). Volatile compounds, such as acetoin and 2, 3butanediol, can stimulate plant growth (Ryu et $a l .$, 2005). Many of the bacterial endophytes promote plant growth indirectly by inhibiting the growth and activities of phytopathogens by the production of antimicrobial substances 
like HCN through a variety of different mechanisms.

Indole acetic acid (IAA) production (Lee et $a l ., 2004)$ by endophytes is another valuable trait that influences plant growth directly (Shi et al., 2009). It has been reported that many endophytes including Enterobacter, Azotobacter, Serratia, Klebsiella spsproduced IAA which stimulated plant growth (Spaepen et al., 2007), In addition to IAA, ammonia production is another plant growth promotion (PGP) trait which has a signalling role between plant and bacterial interactions (Ahemad and Khan, 2010). Ammonia produced by endophytes is used as a source of nitrogen (Deepa et al., 2010). The production of siderophore by endophytes have been reported by Costa and Loper, 1994. Siderophores are biologically active compound with function of chelating iron ions in living organisms. They have found extensive applications in the field of agriculture and medicine.

Endophytic organisms can also supply essential vitamins to plants (Pirttila et al., 2004). Besides, a number of other beneficial effects on plant growth have been attributed to endophytes which include osmotic adjustment, stomatal regulation, modification of root morphology (Compant et al., 2005). In a few cases, endophytes were shown to accelerate seedling emergence and promote plant establishment under adverse conditions (Bent and Chanway, 1998).

\section{Endophytes - Role in secondary metabolite production}

Nowadays interest is growing in exploring the endophyte potential for their plant growth promoting attributes and their usage as a biological control agent of plant pathogens. Most of the endophytes isolated from plants are known for their antimicrobial activity.
They help in controlling microbial pathogens in plants and animals. Traditionally endophytes have been considered an important component of plant defence mechanisms against herbivores and stress tolerance. Plant endophytes protect their host by producing bioactive compounds against phytopathogenic fungi and bacteria. Natural products from endophytic microbes have been observed to inhibit or kill a wide variety of harmful disease-causing organisms including, phyto-pathogens, bacteria, fungi, viruses, and protozoans that generally affects plants and animals. Certain endophyte bacteria trigger a phenomenon known as induced systemic resistance (ISR), which is phenotypically similar to systemic-acquired resistance (SAR). Bacterial endophytes and their role in ISR have been reviewed recently by Kloepper and Ryu (2006). Endophytes may induce plant defence reactions (ISR), leading to a higher tolerance of pathogens (Zamioudis and Pieterse 2012). Bacterial strains of the genera Pseudomonas and Bacillus can be considered the most common groups inducing ISR (Kloepper and Ryu, 2006), although ISR induction is not exclusive to these groups (Bordiec et al., 2011). Bacterial chemical factors responsible for ISR induction were identified to include antibiotics, $\mathrm{N}$ acylhomoserine lactones, salicylic acid, jasmonic acid, siderophores, volatiles (e.g., acetoin), and lipopolysaccharides (Bordiec et al., 2011).

Abundant reports have shown that endophytic microorganisms can have the capacity to control plant pathogens (Krishnamurthy and Gnanamanickam, 1997), insects (Azevedo et al., 2000) and nematodes (Hallmann et al., 1998). Some entomopathogenic fungi can live like endophytes, colonizing plant tissues and providing long lasting protection. Schulz et al., (2002) has shown that it is possible to inoculate entomopathogenic fungi in plants to control insect pests. Beauveria bassiana 
(Bals.) Vuill and Lecanillium dimorphum (JD Chen) Zare and W. Gams can be inoculated in leaves of Phoenix dactylifera L. where they live in the plant tissue (Gomez-Vidal et al., 2006). A comparable effect has been observed when conidia suspensions of this fungus were applied to Zea mays L.; some hyphae grew on the plant cuticle and others penetrated the leaf tissue through the apoplast, reaching the xylem and distributing the fungus internally throughout the rest of the plant, increasing its resistance to the lepidopteran Ostrinia nubilalis Hübner (Wagner and Lewis, 2000). Isolated endophytic strains from Withania coagulans Dunal and Oleaferruginea Royal, were shown secretion of growth promoting substances like IAA, ammonia, phosphate solubilization and also act as biocontrol agents because they produced $\mathrm{HCN}$ and can inhibit phytopathogens as it has antimicrobial activity (Abid Ullah et al., 2018). Hydrolytic enzyme protease is involved in the suppression of pathogenic growth and subsequent reduction in damage to plants (Bashan and Bashan, 2005). Schulz et al., (2002) isolated around 6500 endophytic fungi and tested their biological potential, they analysed 135 secondary metabolites and found that $51 \%$ of bioactive compounds (38\% for soil isolates) isolated from endophytic fungi were new natural products.

Endophyte produced alkaloids in pastures are plant defences (Omacini et al., 2001) in exchange; the endophyte obtaining nutrients and protection inside the plant tissues (Menendez and Bertoni, 1997). Endophytes are capable of synthesizing bioactive compounds that are used by plants for defence against pathogens and some of these compounds have proven to be useful for novel drug discovery. Recent studies have reported hundreds of natural products including alkaloids, terpenoids, flavonoids, and steroids, from endophytes. Most of the bioactive compounds isolated from endophytes are known to have functions of antibiotics, immunosuppressants, anticancer agents, biological control agents, and so forth. A large number of secondary metabolites have been extracted and characterized from endophytic microbes and these are detailed with extensive references (Dreyfuss and Chapela, 1994 and Strobel et al., 2004). Few reports have shown that endophytes can produce secondary compounds similar to those of their host plant, suggesting the possibility of an endophyte-plant genome transfer and expression (Zhang et al., 2006). Dreyfuss and Chapela, 1994 reported that until 2003 approximately 4,000 secondary metabolites with biological activity had been described from fungi. Most of these metabolites are produced by so called "creative fungi" which include species of Acremonium, Aspergillus, Fusarium and Penicillium.

Cryptonectria parasitica, a plant pathogen responsible of chestnut blight, was inhibited by the Epichlöe festucae metabolites indole-3acetic acid (IAA); indole-3-ethanol (IEtOH); methylindole-3-carboxylate; indole-3carboxaldehyde; diacetamide and cyclonerodiol, isolated from its fermentation culture (Yue et al., 2000). Colletotrichum gloeosporides (Penz.) Penz. and Sacc, a plant pathogen found in over 470 host plant genera, produced an antifungal compound (colletotric acid) active against the plant pathogen Helminthosporium sativum when isolated as an endophyte in Artemisia mongolica (Zou et al., 2000). Endophytes can also induce host plant resistance to pathogens (Cavaglieri et al., 2004). It has been modified and inoculated to crop plants to improve their resistance and yield (Kozyrovska et al., 1996). Endophytic microorganisms are regarded as an effective biocontrol agent, alternative to chemical control. An endophytic fungi Beauveria bassiana known as an entomopathogen was found to control 
the borer insects in coffee seedlings (Posada and Vega, 2006) and sorghum (Tefera and Vidal, 2009). The endophytic bacteria Bacillus subtilis, isolated from Speranskia tuberculata (Bge.) Baill, was found to be strongly antagonistic to the pathogen $B$. cinerea in in vitro studies (Wang et al., 2009).Diseases of fungal, bacterial, viral origin and in some instances even damage caused by insects and nematodes can be reduced following prior inoculation with endophytes (Berg and Hallmann, 2006).

The possibility of enhancing plant defences by using their associated endophytes opens an interesting avenue for their use in the control of crop pests and diseases that will be compatible with biological control for use in ecological agriculture. Not all of the endophyte-plant associations make plants more resistant to pests or diseases and we therefore must approach the problem from the outset as a three-way interaction: endophyteplant-organism. Few species of endophytic bacteria are important to crop production because they can be advantageous to infected plants (fixing of nitrogen, plant defences, etc.) and the number of species present in the root system and the relative abundance of each one may be conditioned and/or regulated by the presence of certain endophytes in the plant (Hallman et al., 1998). Chinese cabbage plants whose roots were inoculated with Heteroconium chaetospirae were found resistant to the leaf pathogens Pseudomonas syiringae $p v$. Macricola and Alternaria alternata (Fr.) Keissler (Hashiba and Narisawa, 2005).

\section{Endophytes - Role in abiotic stress tolerance in plants}

Endophytic bacteria and fungi that live within healthy plant tissues promote plant growth under extreme abiotic stress conditions (below or above the optimal levels) which limit plant growth and development. Drought, low/high temperature, salt stress and acidic conditions, heavy metal stress, nutrient stress and starvation are the major abiotic stresses that harm plants. Endophytes employ mechanisms through which plants overcome abiotic stress; these include accumulation of stress-responsible molecules, secondary metabolites, and production of antioxidant enzymes. The root fungal endophyte Piriformospora indica was shown to induce salt tolerance in barley (Baltruschat et al., 2008) and drought tolerance in Chinese cabbage plants (Sun 2010).

An increase in drought resistance has been observed for plants infected with Neotyphodium and barley roots colonized by Piriformospora indica (Waller et al., 2005) and in some cases an increase in nitrogen deficiency tolerance has also been observed (Selosse et al., 2004). Diazotrophic bacteria can positively influence plants by improving growth and root development, which increases plant tolerance to various environmental stresses (Ullah et al., 2015). Abid Ullah et al., (2018), reported that the maximum salt tolerance of endophytic bacteria was observed at $2.5 \%$ and $7.5 \%$ salt concentration. These properties may support host plants to survive under stress conditions by interaction of bacteria and plants.

In conclusion, the endophytes represent an eco-friendly option for the promotion of plant growth and for serving as sustainable resources of novel bioactive natural products. Numerous endophytes and their genes have now been identified, which provide understanding about their behaviour and mechanisms.

Endophytes are well established for their potential to improve plant growth by phosphate solubilisation, nitrogen fixation, and siderophores production. Secondly, 
production of phytohormone like auxins, Cytokinins, gibberellic acids play vital role in plant growth promotions and their growth. Endophytes act as a biological control agent of plant pathogens by these antimicrobial activities and induced systemic resistance mechanisms. Most of endophytes are soil genera, and well recognized for plant growth promotion and production of natural compounds, secondary metabolites which have important role in biotic and abiotic stress tolerance.

The property of endophytes to induce stress tolerance in plants can be applied to increase crop yields. These information encourages use of endophytes in improving crop growth and productivity under non stress and abiotic and biotic stress conditions.

\section{References}

Abid Ullah, Hafsa Mushtaq, Usman Ali, Hakim, Ehsan Ali and Samavia Mubeen (2018) Screening, isolation, biochemical and plant growth promoting characterization of endophytic bacteria. Microbiol Curr Res, 62-68.

Ahemad M and Khan MS (2010) Plant growth promoting activities of phosphatesolubilizing Enterobacter asburiae as influenced by fungicides. Eur Asia J BioSci, 4, 88-95.

Azevedo JL, Maccheroni J Jr, Pereira O and Ara WL (2000) Endophytic microorganisms: a review on insect control and recent advances on tropical plants. Electr J Biotech, 3, 40-65.

Baldani JI, Reis VM, Baldani VLD and Döbereiner J (2002) A brief story of nitrogen fixation in sugarcane - reasons for success in Brazil. Functional Plant Biology, 29, 417-423.

Baltruschat H, Fodor J, Harrach BD, Niemczyk E, Barna B, Gullner G, Janeczko A, Kogel K-H, Schaefer P, Schwarczinger I, Zuccaro A and Skoczowski A (2008) Salt tolerance of barley induced by the root endophyte Piriform ospora indica is associated with a strong increase in antioxidants. New Phytol, 180, 501-510.

Barrow J (2003) Atypical morphology of dark septate fungal root endophytes of Bouteloua in arid southwestern USA rangelands. Mycorrhiza, 13, 239-47.

Bashan Y and de Bashan L (2005) Plant growth-promoting. Enc Soils Environ, 1, 103-15.

Bent E and Chanway CP (1998) The growthpromoting effects of a bacterial endophyte on lodgepole pine are partially inhibited by the presence of other rhizobacteria. Can J Microbiol 44, 980988.

Berg G and Hallmann J (2006) Control of plant pathogenic fungi with bacterial endophytes. Microbial Root Endophytes (Schulz BJE, Boyle CJC and Sieber TN, eds), Springer-Verlag, Berlin, 53-69.

Bordiec S, Paquis S, Lacroix H, Dhondt S, Ait Barka E, Kauffmann S, Jeandet P, Mazeyrat-Gourbeyre F, Clement C, Baillieul F and Dorey S (2011) Comparative analysis of defence responses induced by the endophytic plant growth-promoting rhizobacterium Burkholderia phytofirmans strain PsJN and the non-host bacterium Pseudomonas syringae $p v$. pisi in grapevine cell suspensions. J Exp Bot, 62, 595-603.

Cavaglieri LR, Passone A and Etcheverry MG (2004) Correlation between screening procedures to select root endophytes for biological control of Fusarium verticillioides in Zea mays L. Biol. Control, 31,259-267.

Compant S, Duffy B, Nowak J, Cl C and Barka EA (2005) Use of plant growthpromoting bacteria for biocontrol of plant diseases: principles, mechanisms of action, and future prospects. Appl Environ Microbiol, 71, 4951-4959.

Costa JM and Looper JE (1994) Characterization of siderophore production by the biological-control agent Enterobacter cloacae. Mol Plant Microbe Interact, 7, 440-448. 
Dawwam GE, Elbeltagy A, Emara HM, Abbas IH and Hassan MM (2013) Beneficial effect of plant growth promoting bacteria isolated from the roots of potato plant. Ann Agr Sci, 58, 195-201.

Deepa C, Dastager SG and Pandey A (2010) Isolation and characterization of plant growth promoting bacteria from nonrhizospheric soil and their effect on cowpea (Vigna unguiculata (L.) Walp.) seedling growth. World J Microbiol. Biotechnol, 26, 1233-40.

Dreyfuss MM and Chapela IH (1994) Potential of fungi in the discovery of novel, lowmolecular weight pharmaceuticals. In, Gullao VP ed., The Discovery of Natural Products with Therapeutic Potential Butterworth-Heinemann, London, UK. 49-80.

Dudeja SS, Giri R, Saini R, Suneja-Madan P and Kothe (2012) Interaction of endophytic microbes with legumes. Journal of Basic Microbiology, 52, 248-260.

Gomez-Vidal S, Lopez-Llorca LV, Jansson BH and Salinas JE (2006) Endophytic colonization of date palm (Phoenixdacrylifera L.) leaves by entomopathogenic fungi. Micron, 37, 624-632.

Hallmann J, Quadt-Hallmann A, Rodr'iguezK'abana R \&Kloepper JW (1998) Interactions between Meloidogyne incognita and endophytic bacteria in cotton and cucumber. Soil BiolBiochem, 30, 925-937.

Hamayun M, Afzal Khan S, Ahmad N, DongSheng Tang, San-Mo Kang, Chae-In Na, Eun-Young Sohn, Young-Hyun Hwang, Dong-Hyun Shin, Byung-Hyun Lee, Jong-Guk Kim and In-Jung Lee (2009) Cladosporiums phaerospermum as a new plant growth-promoting endophyte from the roots of Glycine $\max$ (L.) Merr, World Journal of Microbiology and Biotechnology, 25, 627-632.

Hashiba T and Narisawa K (2005) The development and endophyte nature of the fungus Heteroconium chaetospira, FEMS
Microbiol. Lett., 252, 191-196.

Huang L-h, Ao X-J, Shan H, Li h-X, Yang W-X and Zhang h-B (2017) In vitro specific interactions revealed the infective characteristics of fungal endophytes to grapevine. Vitis 56, 71-77.

Kloepper JW and Ryu C-M (2006) Bacterial endophytes as elicitors of induced systemic resistance. Microbial Root Endophytes (Schulz BJE, Boyle CJC \&Sieber TN, eds), Springer-Verlag, Berlin, 33-52.

Kloepper JW, Rodriguez-Kabana R, Zehnder GW, Murphy J, Sikora E and Fernandez C (1999) Plant root-bacterial interactions in biological control of soil borne diseases and potential extension to systemic and foliar diseases. Aust J Plant Pathol, 28, 27-33.

Kobayashi DY and Palumbo JD (2000) Bacterial endophytes and their effects on plants and uses in agriculture. Microbial Endophytes, 19, 199-233.

Kozyrovska N, Kovtunovych G, Gromosova E, Kuharchuk P and Kordyum V (1996) Novel inoculants for an environmentally friendly crop production. Resour. Conser. Recycl, 18, 79-85.

Krings M, Taylor TN, Hass H, Kerp H, Dotzler $\mathrm{N}$ and Hermsen EJ (2007) Fungal endophytes in a 400-million-yrold land plant, infection pathways, spatial distribution, and host responses. New. Phytologist, 174, 648-657.

Krishnamurthy K \& Gnanamanickam SS (1997) Biological control of sheath blight of rice: induction of systemic resistance in rice by plant-associated Pseudomonas spp. CurrSci, 72, 331-334.

Latif S, Khan S, Naveed M, Mustafa G, Bashir T and Mumtaz AS (2013) The diversity of Rhizobia, Sinorhizobia and novel nonRhizobial paenibacillus nodulating wild herbaceous legumes. Arch Microbiol, 195, 647-53.

Lee S, Flores-Encarnacion M, ContrerasZentella M, Garcia-Flores L, Escamilla JE and Kennedy C (2004) Indole-3-acetic acid biosynthesis is deficient in 
Gluconacetobacter diazotrophicus strains with mutations in cytochrome $\mathrm{C}$ biogenesis genes. J Bacteriol, 186, 53845391.

Lodewyckx C, Vangronsveld J, Porteous F, Moore ERB, Taghavi S, Mezgeay $M$ and van der Lelie D (2002) Endophytic bacteria and their potential applications. Crit Rev Plant Sci, 21, 583-606.

Loiret FG, Ortega E, Kleiner D, Ortega-Rodes P, Rodes R and Dong Z (2004) A putative new endophytic nitrogen-fixing bacterium Pantoea sp. from sugarcane. Journal of Applied Microbiology, 97, 504-511.

Lopez BR, Bashan Y and Bacilio M (2011) Endophytic bacteria of Mammillaria fraileana, an endemic rock-colonizing cactus of the southern Sonoran Desert. Arch Microbiol, 193, 527-41.

Ludwig-MuĖller J (2015) Plants and endophytes: equal partners in secondary metabolite production? Biotechnology letters: 1-10.

Menendez A, Bertoni MD and Cabral D (1997) Fungal endophytes in Juncusim bricatus var. chamissonis: identyfication of colonization patterns. Rev. Iberoam. Micol, 14, 125-128.

Mitchell AM, Strobel GA, Hess WM, Vargas PN and Ezra D (2008) Muscodor crispans, a novel endophyte from Ananasananas soides in the Bolivian Amazon. Fungal. Diversity. 31, 37- 43.

Omacini, M, Chaneton EJ, Ghersa CM and Muller CB (2001) Symbiotic fungal endophytes control insect host- parasite interaction webs. Nature, 409, 78-81.

Owen NL and Hundley N (2004) Endophytes the chemical synthesizers inside plants. Science Progress, 87, 79-99.

Pirttilä AM, Joensuu P, Pospiech H, Jalonen J \&Hohtola A (2004) Bud endophytes of Scots pine produce adenine derivatives and other compounds that affect morphology and mitigate browning of callus cultures. Physiol Plant, 121, 305312.

Pocasangre, L, Sikora RA, Vilich V and
Schuster RP (2000) Survey of banana endophytic fungi from central America and screening for biological control of the burrowing nematode (Radopholus similis). Info Musa, 9, 3-5.

Posada F and Vega FE (2005) Establishment of the fungal entomopathogen Beauveria bassiana (Ascomycota: Hypocreales) as an endophyte in cocoa seedlings (The obroma cacao). Mycologia 97, 11951200.

Posada F and Vega FE (2006) Inoculation and colonization of coffee seedlings (Coffea arabica L.) with the fungal entomopathogen Beauveria bassiana (Ascomycota: Hypocreales), Mycoscience, 47, 284-289.

Rodri'guez H and Fraga R (1999) Phosphate solubilizing bacteria and their role in plant growth promotion. BiotechnolAdv, 17, 319-39.

Rosenblueth M and Martinez-Romero E (2006) Bacterial endophytes and their interactions with hosts. Mol Plant Microbe Interact, 19, 827-837.

Ryu CM, Hu CH, Locy RD and Kloepper JW (2005) Study of mechanisms for plant growth promotion elicited by rhizobacteria in Arabidopsis thaliana. Plant Soil, 268, 285-292.

Schulz B, Boyle C, Draeger S, Roemmert A and Krohn K (2002) Endophytic fungi: a source of novel biologically active secondary metabolites. Mycol. Res., 106, 996-1004.

Selosse MA, E Baudoin and Vandenkoornhuyse P (2004) Symbiotic microorganisms, a key for ecological success and protection of plants. Comptes Rendus Biologies, 327, 639-648.

Shi Y, Lou K and Li C (2009) Isolation, quantity distribution and characterization of endophytic microorganisms within sugar beet. African J Biotechnol, 8, 835840.

Spaepen S, Vanderleyden $\mathrm{J}$ and Remans R (2007) Indole-3-acetic acid in microbial and microorganism-plant signalling. FEMS, 31, 425-48. 
Sridhar KR and Raviraja NS (1995) Endophytes- a crucial issue. Current. Sc., 69(7): 570-574.

Strobel G, Daisy B, Castillo U and Harper J (2004) Natural products from endophytic microorganisms. J Nat Prod, 67, 257268.

Sun C, Johnson J, Cai D, Sherameti I, Oelmüeller R and Lou B (2010) Piriformos poraindica confers drought tolerance in Chinese cabbage leaves by stimulating antioxidant enzymes, the expression of drought related genes and the plastid-localized CAS protein. J Plant Physiol, 167, 1009-1017.

Tefera T and Vidal S (2009) Effect of inoculation method and plant growth medium on endophytic colonization of sorghum by the entomopathogenic fungus Beauveria bassiana, BioControl, 54, 663-669.

Ullah A, Heng S, Munis MFH, Fada S and Yang X (2015) Phytoremediation of heavy metals assisted by plant growth promoting (PGP) bacteria: a review. Environ Exp Bot, 117, 28-40.

Wagner BL and Lewis LC (2000) Colonization of corn, Zea mays by the entomopathogenic fungus Beauveria bassiana. Appl. Environ. Microbiol., 66, 3468-73.

Wakelin S, Warren R, Harvey P and Ryder M (2004) Phosphate solubilization by Penicillium spp. closely associated with wheat roots. Bio Fert Soils, 40, 36-43.

Waller F, Achatz B, Baltruschat H, Fodor J, Becker K, Fischer M, Heier T, Hueckelhoven R, Neumann C, von
Wettstein D, Franken P and Kogel, K (2005) The endophytic fungus Piriformos poraindica reprograms barley to saltstress tolerance, disease resistance and higher yield. ProcNatlAcadSci USA. 102, 13386-13391.

Wang S, Hu T, Jiao Y, Wei J and Cao K (2009) Isolation and characterization of Bacillus subtilis EB-28, an endophytic bacterium strain displaying biocontrol activity against Botrytis cinereal Pers. Frontiers of Agriculture in China, 3, 247-252.

Wilson D (1995) Endophyte: the evolution of a term, and clarification of its use and definition, Oikos, 73, 274-276.

Xin G, Zhang G, Kang JW, Staley JT and Doty SL (2009) A diazotrophic, indole-3acetic acid-producing endophyte from wild cottonwood. Biology and Fertility of Soils, 45, 669-674.

Yue Q, Miller CJ, White Jr JF and Richardson MD (2000) Isolation and characterization of fungal inhibitors from Epichloef estucae. Journal of Agricultural and Food Chemistry 48, 4687-4692.

Zamioudis C \&Pieterse CMJ (2012) Modulation of host immunity by beneficial microbes. Mol Plant Microbe Interact, 25, 139-150.

Zhang HW, Song YC and Tan RX (2006) Biology and chemistry of endophytes. Nat Prod Rep, 23, 753-771.

Zou WX, Meng JC, Lu H, Chen GX, Shi GX, Zhang TY and Tan RX (2000) Metabolites of Collectotrichum gloeosporioides, an endophytic fungus in Arteminsia mongolica J. Nat. Prod.,63, 1529-30.

\section{How to cite this article:}

Maiyappan, S., Devendra Kumar and Prasad, TG. 2020. Multiple Roles of Endophytes in Modern Agriculture. Int.J.Curr.Microbiol.App.Sci. 9(08): 2269-2278.

doi: https://doi.org/10.20546/ijcmas.2020.908.260 